\title{
Clinical, biochemical and haemathological effects in Rhamdia quelen exposed to cypermethrin
}

\author{
[Efeitos clínicos, bioquímicos e hematológicos em Rhamdia quelen \\ expostos à cipermetrina] \\ F.P. Montanha ${ }^{1}$, A.C. Fredianelli ${ }^{2}$, R. Wagner ${ }^{2}$, S.R. Sacco ${ }^{3}$, \\ D.C.C. Rocha ${ }^{2}$, C.T. Pimpa $o^{4}$ \\ ${ }^{1}$ Aluno de pós-graduação - Escola de Ciências Agrárias e Medicina Veterinária - PUCPR - Curitiba, PR \\ ${ }^{2}$ Aluno de graduação - Escola de Ciências Agrárias e Medicina Veterinária - PUCPR - Curitiba, PR \\ ${ }^{3}$ Aluna de pós-graduação - UNESP - Botucatu, SP \\ ${ }^{4}$ Escola de Ciências Agrárias e Medicina Veterinária - PUCPR - Curitiba, PR
}

\begin{abstract}
The acute intoxication of Cypermethrin in Silver Catfish (Rhamdia quelen) was evaluated. Animals weighing $56.67 \pm 4.43 \mathrm{~g}$ and measuring $18.92 \pm 1.16 \mathrm{~cm}$ were exposed to sublethal concentrations of Cypermethrin for the species in hydrological conditions during 96 hours. A total of 52 fish divided into three groups were used and received the following concentrations of Cypermethrin: $0(n=12) ; 1.5(n=20)$ and $2.5(\mathrm{n}=20) \mathrm{mg} / \mathrm{L}$. The intoxicated animals suffered behavioral changes such as loss of balance, swimming alteration, dyspnea, upright swimming and sudden spiral swimming movements. As soon as the 96-hour period was over, a blood collection for hematological and biochemical analyses was performed. A complete haemogram test, plasmatic protein test, albumin, alanine transaminase (ALT), aspartate aminotransferase (AST), gamma glutamyltransferase and alkaline phosphatase (ALP) were studied. The values of erythrocytes, hematocrits, haemoglobin, total number of leukocytes, thrombocyte, ALT, AST and ALP changed according to the groups. The results have shown that the environmental contamination by Cypermethrin is toxic to the species.
\end{abstract}

Keywords: fish, biomarkers, ecotoxicology, haemogram, pyrethroids

\section{RESUMO}

Avaliou-se a intoxicação aguda da cipermetrina em jundiás (Rhamdia quelen). Jundiás que pesavam $56,67 \pm 4.43 \mathrm{~g}$ e mediam 18,92 $\pm 1,16 \mathrm{~cm}$ foram expostos a concentrações subletais de cipermetrina para a espécie em 96 horas, via hídrica, utilizando-se 52 peixes, distribuídos em três grupos, segundo a concentração de cipermetrina: $O(n=12) ; 1,5(n=20)$ e 2,5 $(n=20) m g / L$. Os animais intoxicados apresentaram alterações comportamentais, como perda de equilíbrio, dispneia, natação na posição vertical e movimentos bruscos de natação em espiral. Após 96 horas de exposição, foi coletado sangue para análises de hemograma completo, proteína plasmática, albumina, alanina aminotransferase (ALT), aspartato aminotransferase (AST), fosfatase alcalina (ALP) e gamaglutamiltransferase. Os valores de eritrócitos, hematócrito, hemoglobina, número total de leucócitos, número total de plaquetas, ALT, AST e ALP diferiram entre os grupos. Os resultados demonstraram que a contaminação ambiental por cipermetrina é tóxica para a espécie.

Palavras-chave: peixe, biomarcadores, ecotoxicologia, hemograma, piretroides

\section{INTRODUCTION}

After a chemical substance enters an organism, several physiological, hematological and biochemical reactions occur; the organism

Recebido em 6 de julho de 2012

Aceito em 20 de dezembro de 2013

E-mail: chicopm28@yahoo.com.br may adapt to such reactions or they may lead to a toxic state (Begum, 2004; Borges, 2007). The biochemical features are among the more important parameters of the inner parts of fish. The changes in the biochemical profile reflect changes in metabolism and in cell processes in 
the organism, resulting from the effect of several pollutant agents, making it possible to study the mechanisms of the effects of aforementioned substances (Begum, 2004).

Hematological parameters have been increasingly used as indicators of physiological stress resulting from endogenous or exogenous alterations in fish (Lermen et al., 2004). Thus, the evaluation of blood parameters may be useful to monitor the physiological state, for diagnosis of pathologies and fish intoxication (Dörücü and Girgin, 2001; Ranzani-Paiva et al., 2005; Pimpão et al., 2007; Galeb, 2010).

Cypermethrin, a potent wide-spectrum synthetic pyrethroid pesticide, is widely used in sheep wool treatment and in water louse treatment in salmonids cultures (Moore and Waring, 2001). It is frequently used for domestic and industrial pest control (Tripathi and Singh, 2004). Besides, it is also used to control ectoparasites in cattle, sheep, birds and some pets (Velisek et al., 2006).

The compound has been used recently as a chemotherapeutical agent to control ectoparasites and sea lice (Lepeophtheirus salmonis and Caligus elongatus) on Atlantic salmon marine cage cultures (Salmo salar) (Velisek et al., 2006) as well as on several bodies of water to control pests, insects and ectoparasites (Das and Mukherjee, 2003; Tripathi and Singh, 2004), which may cause severe sub chronic and chronic toxicities to fish (Çaliskan et al., 2003). Cypermethrin is a pesticide which has its use restricted by the United States Environmental Protection Agency (USEPA) due to its high toxicity to fish (Saha and Kaviraj, 2009). Silver Catfish (Rhamdia quelen) is a teleost fish, easily found in Central and South Americas, on the Eastern Andes, and in Venezuela (Gomiero et al., 2007). Its culture is growing in southern Brazil (Tavares-Dias et al., 2002).

This study aimed to evaluate the clinical, biochemical and hematological effects on Silver catfish (Rhamdia quelen), exposed to Cypermethrin for 96 hours.

\section{MATERIAL AND METHODS}

Rhamdia quelen, a native river fish from southern Brazil, known as Silver catfish (Brazilian 'jundiá') were used in the experiment that was approved by the Ethics Committee on Animal Use - CEUA/PUCPR (protocol number 439).

The fish were taken from containers and acclimatized for fifteen days in 1000-liter stockaquariums. The water temperature was kept around $24 \sim 25^{\circ} \mathrm{C}$, with constant aeration and biological filtering. The $\mathrm{pH}$ level was around 7.0 and there were two 12-hour periods (illuminated and dark). Fish were fed with commercial fish food once per day and one third of the acclimatizing water was replaced every three days.

On the intoxication day, fish were individually weighted and measured, with an average of $56.67 \pm 4.43 \mathrm{~g}$ and $18.92 \pm 1.16 \mathrm{~cm}$.

During the experiment fish were kept in 30-liter aquariums with the same acclimatizing conditions, but with no food or biofilter. The aquariums were wrapped in dark plastic bags during 96 hours in order to avoid both the photodegradation of the pyrethroid and the stress on the animals due to luminosity.

The fish $(\mathrm{n}=52)$ were randomly divided into three groups exposed to Cypermethrin on the following previously determined sublethal conditions: $0 ; 1.5$ and $2.5 \mathrm{mg} / \mathrm{L}$. Four fish were placed in each aquarium to avoid overcrowding. The group with a $0 \mathrm{mg} / \mathrm{L}$ concentration had three aquariums $(n=12)$, but the two other groups (1.5 and $2.5 \mathrm{mg} / \mathrm{L}$ of Cypermethrin) had five aquariums each $(n=20)$. As for the intoxication itself, Cypermade 250 SC (Cypermethrin, Dipil Brazil) in static system was used.

During the 96-hour period of testing, dead fish were removed from the aquariums and postmortem wounds were analyzed. During the aforementioned period, behavioral changes and clinical signs were observed.

After 96 hours of exposure the fish were anesthetized with benzocaine in $60 \mathrm{mg} / \mathrm{L}$ concentration so that blood collection could be performed using syringes washed with EDTA $3 \%$, by tail vein puncture. The following analyzes were performed: Erythrocyte total numbers, leukocyte differentiation and total number; thrombocyte total number; hematocrit; hemoglobin; plasmatic protein; albumin; alanine 
transaminase (ALT); aspartate aminotransferase (AST); gamma glutamyltransferase (GGT) and alkaline phosphatase (ALP).

The blood extensions were colored using the Rosenfeld method (1947) to perform the leukocyte differential, morphological evaluation, thrombocyte aggregation and hemoparasites research. The erythrocyte, leukocyte and thrombocyte count was manually determined using a Neubauer chamber in an optical microscope after diluting blood in Natt/Herrick's dye, in a 1:200 proportion (1952). The hematocrit was determined in a Microhematocrit centrifuge (SISLAB/MH) running at $11,000 \mathrm{rpm}$ during 5 minutes, and the total plasmatic protein was determined using a refractometer (KERNCO - OS1270). The hemoglobin content, expressed in $\mathrm{g} / \mathrm{dL}$, has been spectrophotometrically determined (Fanen - Excelsa Baby II - mod. 206-R), using Cyan hemoglobin after centrifugation at $3500 \mathrm{rpm}$ during five minutes.

The following biochemical tests were performed with a spectrophotometer (Drake - Quick lab model/Siel - EPECTROMATIC 710 model): Aspartate aminotransferase (AST - IU/L Lab test liquiform), Gamma glutamyltransferase (GGT - IU/L - Lab test liquiform) and albumin (ALBUMINA - g/dL - Lab test colorimetric).

Kruskal-Wallis' test was used to perform the statistical analysis of data; Dunn's test was used afterwards to compare the averages. The significance level adopted was 5\% $(a<0.05)$. All calculations were performed using Graphpad Prism statistical software (version 3.00 for Windows, San Diego - California, USA).

\section{RESULTS}

Fish which died during testing were immediately removed; twelve fish remained in each group up to the end of testing. Before dying, the fish became less active, remaining vertically in the water and, now and then, motionless in the bottom of the aquarium.

Post-mortem alterations observed in animals exposed to Cypermethrin included partial (and, in some cases, total) loss of body surface pigmentation, hyperemic and ulcerated lesions, with hemorrhagic signs in several parts of the body, as well as barbell erosions and tails with a degenerative aspect.

Fish exposed to concentrations of 1.5 and $2.5 \mathrm{mg} / \mathrm{L}$ showed loss of balance, swimming alteration, dyspnea (they kept their mouths and opercula open), upright swimming and sudden spiral swimming movements. Fish exposed to a concentration of $0 \mathrm{mg} / \mathrm{L}$ of Cypermethrin remained healthy during the entire experiment.

Fish exposed to a concentration of $2.5 \mathrm{mg} / \mathrm{L}$ of Cypermethrin tried to jump out of the aquariums. Such signs started on the first 30 minutes after exposure and lasted until the deadline, i.e., 96 hours after the first exposure.

Fish exposed to concentrations of $2.5 \mathrm{mg} / \mathrm{L}$ of Cypermethrin had a significant increase $(\mathrm{P}<0.05)$ of the hematocrit value when compared to the group with concentrations of 0 and $1.5 \mathrm{mg} / \mathrm{L}$ of Cypermethrin, which had averages of $35.80 \pm 3.36 \% ; 31.33 \pm 2.10 \%$ and $31.17 \pm 4.95 \%$, respectively.

Fish exposed to a concentration of $2.5 \mathrm{mg}$ of Cypermethrin had a higher hemoglobin rate $(\mathrm{P}<0.01)$ than fish exposed to a concentration of $1.5 \mathrm{mg} / \mathrm{L}$ of Cypermethrin, having an average of $5.70 \pm 0.80 \mathrm{~g} / \mathrm{dL}$ and $4.64 \pm 0.48 \mathrm{~g} / \mathrm{dL}$, respectively.

Regarding the total number count of erythrocytes, the group with a concentration of $2.5 \mathrm{mg} / \mathrm{L}$ of Cypermethrin had an increase $(\mathrm{P}<0.05)$ when compared to the group with the concentration of $1.5 \mathrm{mg} / \mathrm{L}$, which had an average of $145.8 \pm 17.89$ cells per $\mu \mathrm{L}$ of blood and $122.3 \pm 18.99$ cells per $\mu \mathrm{L}$ of blood, respectively.

Regarding the total number of leukocytes, the group with a concentration of $2.5 \mathrm{mg} / \mathrm{L}$ of Cypermethrin had an average of $134.7 \pm 21.50$ cells per $\mu \mathrm{L}$ of blood, having a significant increase $(\mathrm{P}<0.05)$ when compared to the group with a concentration of $0 \mathrm{mg} / \mathrm{L}$, which had an average of $104.9 \pm 28.8$ cells per $\mu \mathrm{L}$ of blood.

Regarding the differential leukocyte count, there was a tendency of increasing the neutrophils numbers as the animals were exposed to higher concentrations of Cypermethrin, but the alterations were not significant. The neutrophils values obtained by the groups with concentrations of $0 ; 1.5$ and $2.5 \mathrm{mg} / \mathrm{L}$ were 
$8.00 \pm 3.86 \%, \quad 9.00 \pm 7.43 \%$ and $10.67 \pm 2.30 \%$, respectively.

Regarding the differential nucleated cell count, thrombocytes and leukocytes, the number of fish thrombocytes from the group with a concentration of $1.5 \mathrm{mg} / \mathrm{L}$ of Cypermethrin showed an increase $(\mathrm{P}<0.05)$ when compared to the group with a concentration of $0 \mathrm{mg} / \mathrm{L}$ of Cypermethrin, having an average of $78.00 \pm 10.65 \%$ and $65.00 \pm 10.14$, respectively.

Nevertheless, regarding the total number of thrombocytes, fish from the group with a concentration of $2.5 \mathrm{mg} / \mathrm{L}$ of Cypermethrin had an average of $112.7 \pm 29.18$ cells per $\mu \mathrm{L}$ of blood, with an increased value $(\mathrm{P}<0.05)$ when compared to fish from the group with a concentration of $0 \mathrm{mg} / \mathrm{L}$ of Cypermethrin, which had an average of $77.64 \pm 21.80$ cells per $\mu \mathrm{L}$ of blood.

There was no significant difference $(\mathrm{P}<0.05)$ among the analyzed groups regarding the neutrophil, lymphocytes, monocyte, eosinophil, basophil, immature cell and plasmatic protein parameters.

After 96 hours of exposure to Cypermethrin, fish from the groups with concentrations of 1.5 and $2.5 \mathrm{mg} / \mathrm{L}$ had a significant decrease $(\mathrm{P}<0.05$ and $\mathrm{P}<0.01$, respectively) in values of alanine aminotransferase (ALT) enzyme when compared to fish from the group with a concentration of $0 \mathrm{mg} / \mathrm{L}$ of Cypermethrin, having an average of $18.11 \pm 4.83 \mathrm{IU} / \mathrm{L} ; 17.11 \pm 5.80 \mathrm{IU} / \mathrm{L}$ and $26.33 \pm 6.08 \mathrm{IU} / \mathrm{L}$, respectively.

Fish exposed to the highest concentration of Cypermethrin $(2.5 \mathrm{mg} / \mathrm{L})$ had a significant increase $(\mathrm{P}<0.05)$ in aspartate aminotransferase (AST) when compared to the group with a concentration of $0 \mathrm{mg} / \mathrm{L}$, which had an average of $173.0 \pm 49.34 \mathrm{IU} / \mathrm{L}$ and $109.4 \pm 33.92 \mathrm{IU} / \mathrm{L}$, respectively.

Regarding alkaline phosphatase (ALP), it was possible to observe a significant decrease $(\mathrm{P}<0.01$ and $\mathrm{P}<0.001)$ in fish exposed to concentrations of 1.5 and 2.5 of Cypermethrin, when compared to the group with a concentration of $0 \mathrm{mg} / \mathrm{L}$; as the Cypermethrin concentration increases, the ALP values decrease. Groups with concentrations of $0 ; 1.5$ and $2.5 \mathrm{had}$ an average of $33.83 \pm 5.09 \mathrm{IU} / \mathrm{L}$;
$26.40 \pm 2.36 \mathrm{IU} / \mathrm{L}$ and $22.75 \pm 5.41 \mathrm{IU} / \mathrm{L}$, respectively.

Regarding albumin and gamma glutamyltransferase (GGT), there was no significant difference $(\mathrm{P}>0.05)$ among the groups.

\section{DISCUSSION}

When animals, in general, are exposed to different substances considered to be potentially toxic, several endogenous alterations may happen. In this study, animals exposed to concentrations of 1.5 and $2.5 \mathrm{mg} / \mathrm{L}$ of Cypermethrin had neurological, breathing and behavioral changes such as loss of balance, swimming alterations, dyspnea (they kept their mouths and opercula open), upright swimming and sudden spiral swimming movements. Such results corroborate with Polat et al. (2002), who tested Cypermethrin in guppies (Poecilia reticulata) and Borges (2007), who tested Cypermethrin in Silver catfish (Rhamdia quelen). Kumar et al. (2007), when exposing Channa punctatus to Cypermethrin, also reported such alterations.

In all aforementioned studies related to Cypermethrin, regardless of the species exposed, concentrations below the ones used in this study ( 1.5 and $2.5 \mathrm{mg} / \mathrm{L})$ were used, showing that the species used is more resistant than the ones used by those authors. Borges (2007), by exposing Silver catfish (Rhamdia quelen) to Cypermethrin, obtained the same responses as this study, but used much lower concentrations than the ones used in this study (0.08 to $0.24 \mathrm{ppm})$. This difference may be related with the animals' gender and size, since Borges used larger and heavier male animals, when compared to the ones used in this study. The difference may also be related both to the toxicity of the formulation of the tested active substance and the acclimatizing period being shorter than the one used on this study, which is considered a stressing factor to the animals.

Such clinical and behavioral alterations may be attributed to the neurotoxic effect of the pyrethroids, due to sodium channel blocking and the inhibition of GABA receptors on nerve filaments, which caused an excessive stimulation of the central nervous system, which could lead to cerebral hypoxia (El-Sayed et al., 2007). 
Kumar et al. (2007) tested concentrations of 0.3, $0.4,0.5$ and $0.6 \mathrm{mg} / \mathrm{L}$ of Cypermethrin in Channa punctatus, which presented the first clinical signs after three hours of exposure, incompatible with this study, which observed that the aforementioned clinic signs have started before completing an hour of exposure.

Galeb (2010) when exposing Silver catfish under Deltamethrin effects, observed that the body color of the animals changed, showing a whitish color; this result was also observed in this study, being more perceptible in post-mortem alterations; they also presented hemorrhagic dots and ulcerated lesions throughout their bodies. Such alterations are the result of the irritating effect of Cypermethrin in aquatic organisms.

In this study, the group exposed to a concentration of $2.5 \mathrm{mg} / \mathrm{L}$ of Cypermethrin had a significant $(\mathrm{P}<0.05)$ increase in the hematocrit rate when compared to groups exposed to lower Cypermethrin concentrations. Nevertheless, results found by Dörürü and Girgin (2001), who tested Cypermethrin in Common carp (Cyprinus carpio), have shown hematocrit rate decreasing in fish after exposure.

According to Tavares-Dias et al. (2002), the reference values of hematocrit for Silver catfish are between $17 \%$ and $34 \%$, compatible with this study, in which the group that was not exposed to Cypermethrin had its hematocrit rate inside this range $(31.33 \%)$.

Borges (2007) reported hemoglobin increase in Silver catfish (Rhamdia quelen) exposed to Cypermethrin, corroborating with the results of this study with Silver catfish exposed to a concentration of $2.5 \mathrm{mg} / \mathrm{L}$ of Cypermethrin when compared to the group exposed to a concentration of $1.5 \mathrm{mg} / \mathrm{L}(\mathrm{P}<0.01)$. On the other hand, Dörücü and Girgin (2001) and Das and Mukherjee (2003), when testing Cypermethrin in Common carp (Cyprinus carp) and carp (Labeo rohita), respectively, observed a decrease in the hemoglobin rate in the groups exposed to pyrethroid when compared to the control group.

According to Tavares-Dias et al. (2002), the reference value for hemoglobin in Silver catfish is between 4.95 and $9.09 \mathrm{~g} / \mathrm{dL}$, which corroborates the value found in this study on the group free of Cypermethrin $(5.24 \mathrm{~g} / \mathrm{dL})$.
In this study, the total number of erythrocytes count in the group with a concentration of $2.5 \mathrm{mg} / \mathrm{L}$ of Cypermethrin showed an increase $(\mathrm{P}<0.05)$ when compared to the group $1.5 \mathrm{mg} / \mathrm{L}$. Dörücü and Girgin (2001) and Saxena and Seth (2002), when evaluating effects of Cypermethrin on Cyprinus capio and Channa punctatus, respectively, reported a decrease in red cells in the animals exposed to pyrethroid. Velisek et al. (2006) and Das and Mukherjee (2003), when testing Cypermethrin in rainbow trout (Oncorhynchus mykiss) and carp (Labeo rohita), respectively, did not report alterations on the erythrocytes values among the groups exposed to the chemical compound and the control group.

Alterations on the hematocrit, hemoglobin and erythrocyte rates may be attributed to the erythropoiesis reactivation mechanism induced by spleen and liver, in response to the cerebral hypoxia caused by pyrethroid (Pimpão et al., 2007).

In this study, Silver catfish exposed to a higher concentration of Cypermethrin have shown an increase $(\mathrm{P}<0.05)$ in the total counting of leukocytes when compared to the group free of Cypermethrin, compatible with results found by Das and Mukherjee (2003) when testing Cypermethrin in carp (Labeo rohita). Nevertheless, Dörücü and Girgin (2001) and Velisek et al. (2006), when testing Cypermethrin in the Common carp (Cyprinus carp) and rainbow trout (Oncorhynchus mykiss), respectively, reported a decrease in the leukocyte number of the intoxicated groups.

Leukocytosis may be related to immunogenic stimulus as a response to the Cypermethrin effects on fish.

Velisek et al. (2006), when exposing rainbow trout (Oncorhynus mykiss) under Cypermethrin effect, reported a decrease in the total thrombocyte counting. The decrease of this parameter is related to the stress degree of fish during collection, since cortisol released during stress is an important causing factor of thrombocyte quantity and quality decrease (Galeb, 2010); such results are different from the ones found in this study. There has been no decrease in thrombocytes, including the Cypermethrin-free group, which can be explained due to the fact that fish have been 
anesthetized during blood collection, since the value obtained in this study is between the ones considered as reference for Silver catfish (Tavares-Dias et al., 2002). The increase $(\mathrm{P}<0.05)$ in the number of thrombocytes in the group exposed to a higher concentration of Cypermethrin $(2.5 \mathrm{mg} / \mathrm{L})$ when compared to the group with a concentration of $0 \mathrm{mg} / \mathrm{L}$ in this study may be associated to a compensatory response of the organism due to the hemorrhagic dots present in the animals' bodies. The aforementioned cells have a fundamental role in the organic defense and in the hemostasis (Satake et al., 2009).

In this study, fish had a significant decrease $(\mathrm{P}<0.05$ for the concentration of $1.5 \mathrm{mg} / \mathrm{L}$ of Cypermethrin and $\mathrm{P}<0.01$ for the concentration of $2.5 \mathrm{mg} / \mathrm{L}$ of Cypermethrin) in the value of alanine transaminase (ALT) obtained, when compared to the group with concentration $0 \mathrm{mg} / \mathrm{L}$, indicating hepatic degradation. Such values corroborate the results obtained in studies performed by Borges (2007) when exposing Silver catfish (Rhamdia quelen) to Cypermethrin. Nevertheless, Begum (2005), when testing Cypermethrin in Walking catfish (Clarias batrachus), reported an increase of ALT values in the animals exposed to the pyrethroid when compared to the control group.

An increase $(\mathrm{P}<0.05)$ in the value of aspartate aminotransferase (AST) was observed in this study, concerning the group exposed to the concentration of $2.5 \mathrm{mg}$ of Cypermethrin when compared to the one exposed to the concentration of $0 \mathrm{mg} / \mathrm{L}$, corroborating with Begum (2005) and Borges (2007), which have tested Cypermethrin in Walking catfish (Clarias batrachus) and Silver catfish (Rhamdia quelen), respectively.

The increase in the activity of aspartate aminotransferase (AST) is related to the Hepatic Parenchyma, which suggests reinforcement on the protein catabolism and hepatocellular damage in the organism (Begum, 2005). This is actually expected as a response of the organisms under effect of acute intoxication.
Alkaline phosphatase (ALP) values on Silver catfish exposed to Cypermethrin concentrations of 1.5 and $2.5 \mathrm{mg} / \mathrm{L}$ have decreased $(\mathrm{P}<0.01$ and $\mathrm{P}<0.001$, respectively) when compared to the group with a concentration of $0 \mathrm{mg} / \mathrm{L}$. These results corroborate the ones found by Das and Mukherjee (2003) and Velisek et al. (2006), who tested Cypermethrin in Carp (Labeo rohita) and rainbow trout (Oncorhynchus mykiss), respectively. On the other hand, Borges (2007) and Saha and Kaviraj (2009), when exposing Silver catfish (Rhamdia quelen) and catfish (Heteropneustes fossilis), respectively, under Cypermethrin effect, have reported ALP increase in their studies. A decrease in ALP levels may be related to the destruction of the cell membrane of hepatocytes, demonstrating toxic insult (Galeb, 2010).

Alanine transaminase (ALT) and aspartate aminotransferase (AST) enzymes are the most important aminotransferases related with amino acid metabolism in the liver of teleost fish (Coz-Rakovac et al., 2008). On the other hand, alkaline phosphatase (ALP) and gamma glutamyltransferase (GGT) are important enzymes in the detection of the cell membrane of hepatocytes destruction (Kramer and Hoffmann, 1997). It is unknown, in fish, of the existence of ALP isoenzymes similar to the ones found in mammals (Hubrec et al., 2001).

\section{CONCLUSION}

Cypermethrin has caused significant biochemical alterations, showing hepatic damage in silver catfish as a tissue response to the aforementioned insecticide. Silver catfish (Rhamdia quelen) has proven itself more resistant under the effect of pyrethroids when compared to other fish species; nevertheless, Cypermethrin may be considered toxic to the analyzed species, since the analyzed animals have shown behavioral alterations, clinical signs, hematological and biochemical alterations which have been evident on those studied, which are compatible with the aforementioned intoxication, besides the observed partial mortality. 


\section{REFERENCES}

BEGUM, G. Carbofuran insecticide induced biochemical alterations in liver and muscle tissues of the fish Clarias batrachus (linn) and recovery response. Aquat. Toxicol., v.66, p.8392, 2004.

BEGUM, G. In vivo biochemical changes in liver and gill of Clarias batrachus during cypermethrin exposure and following cessation of exposure. Pestic. Biochem. Phys., v.82, p.185196, 2005.

BORGES, A. Changes in hematological and serum biochemical values in Jundiá Rhamdia quelen due to sub-lethal toxicity of cipermethrin. Chemosphere, v.69, p.920-926, 2007.

ÇALISKAN, M.; ERKMEN, B.; YERLI, S.V. The effects of zeta cypermethrin on the gills of common guppy Lebistes reticulates. Elsevier. Environ. Toxicol. Phar., v.14, p.117-120, 2003.

COZ-RAKOVAC, R.; SMUC, T.; TOPIC POPOVIC, N. et al. Novel methods for assessing fish blood biochemical data. J. Appl. Ichthyol., v.24, p.77-80, 2008.

DAS, B.K.; MUKHERJEE, S.C. Toxicity of cypermethrin in Labeo rohita fingerlings: biochemical, enzymatic and haematological consequences. Comp. Biochem. Phys., v.134, p.109-121, 2003.

DÖRÜCÜ, M.; GIRGIN, A. The effect of cypermethrin on some haematological parameters of Cyprinus capio. Aquacult. Int., v.9, p.183-187, 2001.

EL-SAYED, Y.S.; SAAD, T.T.; EL-BAHR, S.M. Acute intoxication of deltamethrin in monosex Nile Tilapia, Oreochromis niloticus with special reference to the clinical, biochemical and haematological effects. Environ. Toxicol. Phar., v.24, p.212-217, 2007.

GALEB, L.A.G. Avaliação dos efeitos toxicológicos da deltametrina em uma espécie de peixe fluvial nativo jundiá (Rhamdia quelen). 2010. 70f. Dissertação (Mestrado em Ciência Animal) - Programa de Pós-Graduação em Ciência Animal, Pontifícia Universidade Católica do Paraná, Curitiba.
GOMIERO, L.M.; SOUZA, U.P.; BRAGA, F.M.S. Reprodução e alimentação de Rhamdia quelen (Quoy and Gaimard, 1824) em rios do Núcleo Santa Virgínia, Parque Estadual da Serra do Mar, São Paulo, SP. Biota Neotrop., v.7, p.127-133, 2007.

HUBREC, T.C.; SMITH, S.A.; ROBERTSON, J.L. Age-related changes in hematology and plasma chemistry values of hybrid striped bass (Morone chrysops X Morone Saxatilis). Vet. Clin. Path., v.30, p.8-15, 2001.

KRAMER, J.W.; HOFFMANN, W.E. Clinical Enzymology. In: KANEKO, J.J.; HARVEY, J.W.; BRUSS, M.L. Clinical Biochemistry of Domestic Animals. 5.ed. California: ACADEMIC PRESS, 1997. p.315.

KUMAR, A.; SHARMA, B.; PANDEY, R.S. Preliminary evaluation os the acute toxicity of cypermethrin and $\alpha$-cyhalothrin to Channa punctatus. B. Environ. Contam. Tox., v.79, p.613-616, 2007.

LERMEN, C.L.; LAPPE, R.; CRESTANI, M. et al. Effect of different temperature regimes on metabolic and blood parameters os silver catfish Rhamdia quelen. Elsevier, Aquaculture, v.239, p.497-507, 2004.

MOORE, A.; WARING, C.P. The effects of a synthetic pyrethroid pesticide on some aspects of reproduction in Atlantic Salmon (Salmo salar L.). Aquat. Toxicol., v.52, p.1-12, 2001.

PIMPÃO, C.T.; ZAMPRONIO, A.R.; SILVA DE ASSIS, H.C. Effects os deltamethrin on hematological parameters and enzymatic activity in Ancistrus multispinis (Pisces, Teleostei). Pestic. Biochem. Phys., v.88, p.122-127, 2007.

POLAT, H.; ERKOÇ, F.U.; VIRAN, R.; KOÇAK, O. Investigation of acute toxicity of beta-cypermethrin on guppies Poecilia reticulata. Chemosphere, v.49, p.39-44, 2002.

RANZANI-PAIVA, M.J.T.; ROMAGOSA, E.; ISHIKAWA, C.M. Hematological parameters of "cachara", Pseudoplatystoma fasciatum Linnaeus, 1766 (Osteichthyes, pimelodidae), Reared in captivity. Bol. Inst. Pesca, v.31, p.4753, 2005. 
SAHA, S.; KAVIRAJ, A. Effects os cypermethrin on some biochemical parameters and its amelioration through dietary supplementation os ascorbic acid in freshwater catfish Heteropneustes fossilis. Chemosphere, v.74, p.1254-1259, 2009.

SATAKE, F.; PÁDUA, S.B.; ISHIKAWA, M.M. Distúrbios morfológicos em células sanguíneas de peixes em cultivo: uma ferramenta prognóstica. In: TAVAREZ-DIAS, M. Manejo $e$ sanidade de peixes em cultivo. Macapá: EMBRAPA Amapá, 2009. p.330-345.

SAXENA, K.K.; SETH, N. Toxic effects os cypermethrin on certain hematological aspects of fresh water fish Channa punctatus. B. Environ. Contam. Tox., v.69, p.364-369, 2002.
TAVARES-DIAS, M.; MELO J.F.B.; MORAES, G.; MORAES, F.R. Características hematológicas de teleósteos brasileiros. IV. Variáveis do Jundiá Rhamdia quelen (Pimelodidae). Cienc. Rural, v.32, p.693-698, 2002.

TRIPATHI, P.K.; SINGH, A. Toxic effects of cypermethrin and alphamethrin on reproduction and oxidative embolism of the freshwater snail, Lymnaea acuminate. Ecotox. Environ. Safe., v.58, p.227-235, 2004.

VELISEK, J.; WLASOW, T.; GOMULKA, P. et al. Effects of cypermethrin on rainbow trout (Oncorhynchus mykiss). Vet. Med-Czech, v.51, p.469-476, 2006. 